ISSN 0258-7122 (Print), 2408-8293 (Online)

Bangladesh J. Agril. Res. 41(2): 335-344, June 2016

\title{
INHERITANCE MECHANISM OF YIELD AND YIELD COMPONENTS IN TOMATO
}

\author{
M. A. GOFFAR ${ }^{1}$, A. AHMED ${ }^{2}$ AND G. M. A. HALIM ${ }^{3}$
}

\begin{abstract}
A set of 9x9 half diallel cross comprising of promising genotypes was studied to analyze the inheritance pattern of yield components in tomato. Hayman's analysis of variance (ANOVA) indicated importance of both additive and nonadditive genetic components for all the thirteen yield contributing characters. The ANOVA showed unidirectional dominance, asymmetrical gene distribution and residual dominance effects for all the characters studied. Five out of the thirteen characters viz., number of flowers/cluster, individual fruit weight, fruit breadth, number of locules and number of seeds/fruit followed the simple additive-dominance genetic model. The rest of the characters showed non-allelic gene interaction or epistasis. $\mathrm{P}_{6}$ had most of the dominant genes for both number of flowers/cluster and number of locules, while $\mathrm{P}_{3}$ contained most dominant genes for individual fruit weight and $\mathrm{P}_{5}$ possessed that for both fruit breadth and number of seeds/fruit. The estimates of components of variance demonstrated involvement of both additive and dominant components in the inheritance of all those five characters. The distribution of dominant and recessive genes was equal in the parents for only fruit breadth. There was drastic influence of environment on these characters following simple additive-dominance genetic model except fruit breadth.
\end{abstract}

Keywords: Tomato, inheritence, additive and non-additive genetic components, epistasis.

\section{Introduction}

Tomato (Solanum lycopersicum L.) is one of the most important vegetables of Bangladesh. It is rich in a plethora of natural antioxidants and bioactive compounds. The regular ingestion of an adequate amount of fresh tomatoes or processed tomato products has been inversely correlated with the development of widespread human diseases (Erdman et al., 2009 and Prakash et al., 2014 ) and with an increase in plasma lipid peroxidation levels (Balestrieri et al., 2004).This protective effect has been mainly attributed to the carotenoid constituents of the fruits, particularly lycopene and $\beta$-carotene which act as antioxidants in detoxifying free radicals (Erdman et al., 2009). In Bangladesh, national average yield is $10.0 \mathrm{t} / \mathrm{ha}$ (Annon. 2014), which is very low compared to other tomato growing countries. So yield of tomato is to be increased several

\footnotetext{
${ }^{1}$ Senior Scientific Officer, Olericulture Division, Horticultural Research Centre, Bangladesh Agricultural Research Institute (BARI), Gazipur-1701, ${ }^{2}$ Scientific Officer, Plant Breeding Division, BARI, Gazipur-1701, ${ }^{3}$ Chief Scientific Officer, Olericulture Division, Horticultural Research Centre, BARI, Gazipur-1701, Bangladesh.
} 
folds in a unit area. It is reported that hybrid variety of tomato resulted in increased yield of 20 to $50 \%$. Apart from high yield, the hybrids may have some other specific advantages of earliness, higher number of fruits per plant, fruit size, improved quality, uniformity, higher adaptation capability to adverse conditions etc. It was further mentioned that exploitation of hybrid vigor in tomato is economical because each fruit contains larger number of seeds as compared to other vegetables and per unit area seed requirement is also very little. At present, farmers are very interested to grow hybrid variety for avoiding disease problem and to get early harvest (short duration), good quality fruit along with better yield. But there is lacking of good hybrid varieties, though different seed companies are advertising different advantages to attract farmers. Most of the hybrid tomato varieties cultivated in Bangladesh are imported. BARI has so far developed nine hybrid tomato varieties (four varieties already obsolete). Therefore, more hybrid varieties need to be developed and seeds of those tomato varieties can be produced locally and marketed at lower price compared to imported varieties.

The improvement program of tomato can be enhanced to considerable extent if some basic information relevant to the pattern and genetic variability is made available to the plant breeders. The inheritance pattern and combining ability studies are the basic themes to derive such information which can be used as guidelines in planning tomato breeding program for achieving short and long term objectives.

Gene action refers to the mode of expression of genes in a breeding population. Mode of gene action provide guidelines in the selection of parents for utilization in hybridization program as well as choice of breeding procedures for genetic improvement of various quantitative traits of interest. Its main attributes include genetic components of variance which comprises the magnitude of combining ability variances and their relative effects. On the basis of genetic variance, gene action is being described in three different forms i.e., additive gene action, dominant gene action and epistatic gene action, respectively. The later two are collectively termed as non-additive gene action. Different factors affect the mode of gene action which includes type of genetic material utilized, mode of pollination, pattern of inheritance, sample size, sampling methods, existence of linkages and methods of derivation on gene action. Therefore, it was tried to define the inheritance pattern of some yield contributing characters of tomato which would be helpful for further breeding program.

\section{Materials and Method}

The experiment was carried out at the experimental field of Olericulture Division of HRC, BARI during winter season of 2013-14. Nine genotypes of tomato viz., $\mathrm{P}_{1}$ (TLB-182), $\mathrm{P}_{2}$ (BARI Tomato 15), $\mathrm{P}_{3}$ (BARI Tomato 2), $\mathrm{P}_{4}$ (GWT-038), $\mathrm{P}_{5}$ 
(BARI Tomato 14), $\mathrm{P}_{6}$ (GWT 034), $\mathrm{P}_{7}$ (GWT 070), $\mathrm{P}_{8}$ (TLB-182PE) and $\mathrm{P}_{9}$ (SL(CNG) 010) with different characters were crossed in diallel fashion excluding reciprocals. The seeds of these tomato lines were sown in the seedbed on October 16, 2013. Thirty days old seedlings were transplanted in the main plot on November 15, 2013. The crop was fertilized with cow dung $10 \mathrm{t}$, urea $550 \mathrm{~kg}$, TSP $450 \mathrm{~kg}$ and MOP $250 \mathrm{~kg}$ per ha, respectively. Half cow dung, entire TSP and half of MOP were applied during land preparation. The remaining half of the cow dung was applied during pit preparation. The rest of MOP and entire urea were applied at three equal installments at 15, 30 and 45 days after transplanting. Gap filling, plant protection, irrigation and other intercultural operations were done as and when necessary.

Measured characters and data collection: Data on thirteen yield and yield attributing parameters (given below) were recorded from 20 inner plants of each plot escaping border plants following AVRDC guideline:

Data on days to $50 \%$ flowering (DF), number of flowers/cluster (F/C), number of flower clusters/plant $(\mathrm{C} / \mathrm{P})$, days to first harvest $(\mathrm{DFH})$, number of fruits/plant $(\mathrm{F} / \mathrm{P})$, individual fruit weight (IFW), harvest duration (HD), plant height $(\mathrm{PH})$, fruit length (FL), fruit breath (FB), number of locules (NL), number of seeds/fruit $(\mathrm{S} / \mathrm{F})$ and fruit yield/plant (FY/P).

Design and statistical analysis: The experiment was laid out in randomized complete block design (RCBD) with 3 replications. The size of unit plot was $4.8 \mathrm{~m} \times 1 \mathrm{~m}$, and the plant spacing was $60 \mathrm{~cm} \times 40 \mathrm{~cm}$. Each unit plot contained 2 rows of plants ( 24 plants/ plot). The recorded quantitative data were analyzed statistically for analysis of variance and $\mathrm{Vr}-\mathrm{Wr}$ graph following Hayman (1954a) and Hayman (1954b). Components of genetic parameters were calculated following numerical approach of Jinks and Hayman (1953) based on Mather's notation (Mather and Jinks, 1982).

\section{Results and Discussion}

Preliminary ANOVA : From the preliminary ANOVA (Table 1) it was observed that all the thirteen characters showed highly significant mean sum of squares due to genotypes, which indicated significant differences among genotypes and we would proceed forward with all those characters.

Morley Jones ANOVA : Additive (a) and dominance (b) components of all the studied traits showed significant to highly significant mean sum of squares (Table 2), which proved the importance of both additive and dominance genetic components for the inheritance of those traits and the authenticity of further $\mathrm{Vr}$ Wr graph analysis. 


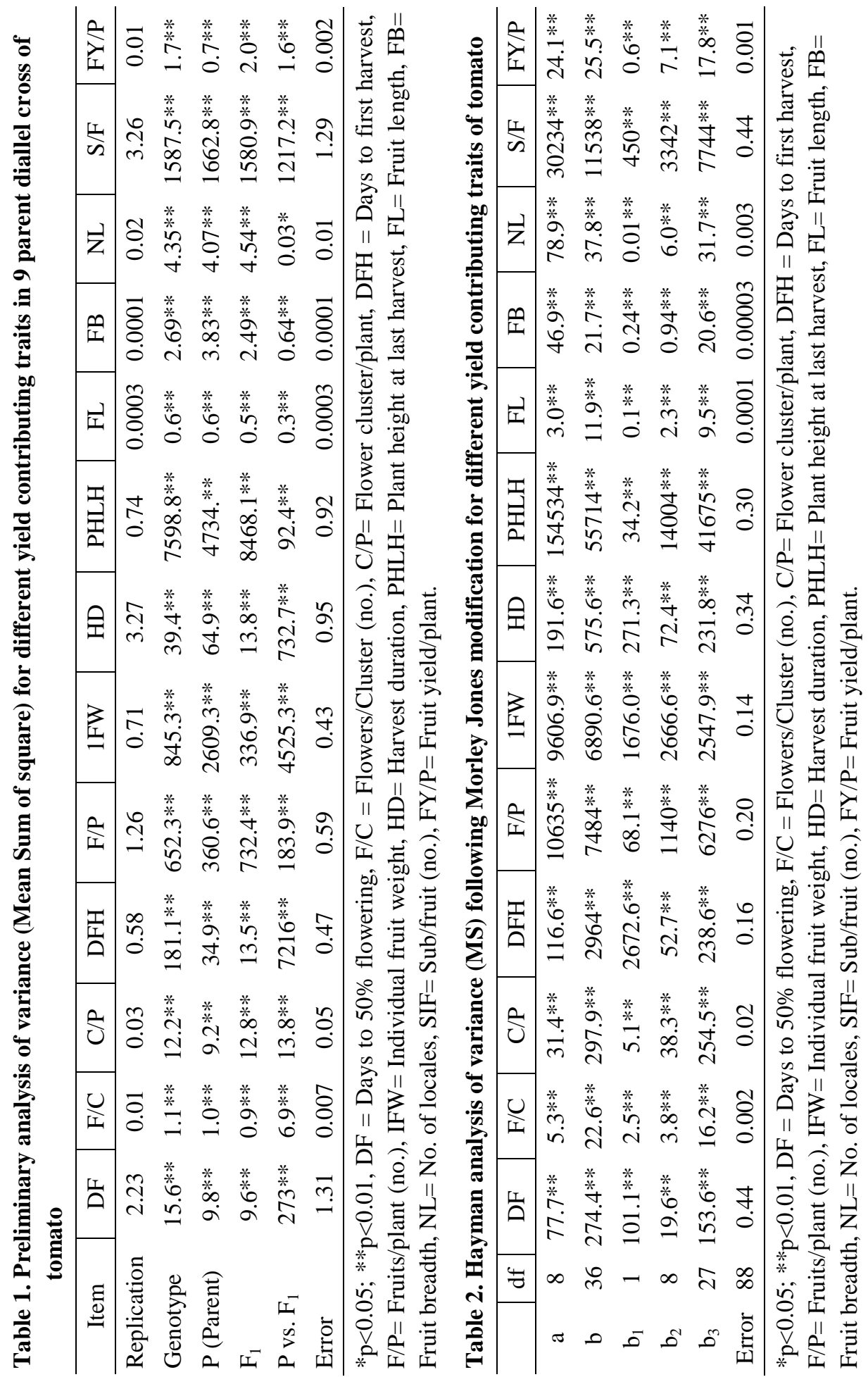


Unidirectional dominance and significant differences between mean of hybrids and mid parental value (significant $b_{1}$ ) were observed for days to $50 \%$ flowering, number of flowers/cluster, number of flower clusters/plant, days to first harvest, number of fruits/plant, individual fruit weight, harvest duration, plant height at last harvest, fruit length, fruit breath number of locules, number of seeds/fruit and fruit weight/plant. Highly significant $b_{1}$ component for number of flowers/cluster, fruit width, days to first fruit ripening, plant hight was found by Gul (2011). Again, asymmetrical gene distribution (significant $b_{2}$ ) was obtained for all the traits examined. Finally, the significant residual dominance effects $\left(b_{3}\right)$ which is specific to individual crosses, was found for all the studied traits. Gul (2011) also observed significant $b_{2}$ and $b_{3}$ for all the characters he had studied.

Vr-Wr graph: From the Vr-Wr related statistical analysis, it was observed that only five traits out of thirteen traits, fulfilled the assumptions related to the simple additive-dominance genetic model, while the others exhibited epistasis or non allelic gene interaction (Table 3). Therefore, the Vr-Wr graph and Hayman's numerical approach had been subjected for number of flowers/cluster, individual fruit weight, fruit breadth, number of locules and number of seeds/fruit only. Bhutani and Kalloo (1991) found similar result for number of locules, while Ahmed et al. (2010), observed for fruit breath and number of seeds/plant. In contrast to the result fully adequate additive dominance model were found by Gul (2011) for plant height and number of fruits per plant.

Tabele 3. Statistics related to $\mathrm{Vr}-\mathrm{Wr}$ analysis for different yield contributing traits in a 9-parent diallel cross of tomato

\begin{tabular}{l|c|c|c|c|c|c|c}
\hline \multicolumn{1}{c}{ Characters } & $\mathrm{a}$ & $\mathrm{b}$ & $\begin{array}{c}\mathrm{SE} \\
(\mathrm{b})\end{array}$ & $\mathrm{b}=1$ & $\mathrm{~b}=0$ & $\mathrm{t}^{2}$ & $\begin{array}{c}\text { Significance } \\
\text { of }^{2}\end{array}$ \\
\hline Days to 50\% flowering & -0.69 & 0.36 & 0.20 & $*$ & $\mathrm{~ns}$ & 2.25 & $\mathrm{~ns}$ \\
Number of flowers/cluster & -0.16 & 0.53 & 0.21 & $\mathrm{~ns}$ & $*$ & 0.85 & $\mathrm{~ns}$ \\
Number of flower clusters/ plant & -0.06 & 0.03 & 0.29 & $*$ & $\mathrm{~ns}$ & 0.53 & $\mathrm{~ns}$ \\
Days to first harvest & -21.82 & 0.58 & 0.07 & $* *$ & $* *$ & 19.14 & $* *$ \\
Number of fruits/plant & 25.79 & 0.28 & 0.06 & $* *$ & $* *$ & 58.34 & $* *$ \\
Individual Fruit weight & 67.51 & 0.93 & 0.10 & $\mathrm{~ns}$ & $* *$ & 0.07 & $\mathrm{~ns}$ \\
Harvest duration & 3.06 & 0.12 & 0.02 & $* *$ & $* *$ & 860.02 & $* *$ \\
Plant height at last harvest & -34.98 & 0.63 & 0.11 & $* *$ & $* *$ & 6.08 & $*$ \\
Fruit length & 0.06 & -.23 & .28 & $* *$ & $\mathrm{~ns}$ & 0.52 & $\mathrm{~ns}$ \\
Fruit breath & 0.12 & 0.79 & 0.22 & $\mathrm{~ns}$ & $* *$ & 0.00 & $\mathrm{~ns}$ \\
Number of locules & -0.13 & 0.81 & 0.22 & $\mathrm{~ns}$ & $* *$ & 0.00 & $\mathrm{~ns}$ \\
Number of seeds/fruit & 54.98 & 0.57 & 0.23 & $\mathrm{~ns}$ & $*$ & 0.39 & $\mathrm{~ns}$ \\
Fruit yield/plant & 0.02 & 0.05 & 0.05 & $* *$ & $\mathrm{~ns}$ & 118.02 & $* *$ \\
\hline
\end{tabular}

$* \mathrm{p}<0.05 ; * * \mathrm{p}<0.01$. 
Partial dominance in the inheritance was observed for individual fruit weight, fruit breath and number of seeds/fruit as their regression line intercepted $\mathrm{Wr}$-axis above the origin with the 'a' value of $67.51,0.12$ and 54.98 , respectively. On the contrary, number of flowers/cluster and number of locules showed over dominance as regression lines intercepted $\mathrm{Wr}$-axis below the origin with the negative value of ' $a$ ' -0.16 and -0.13 , respectively. These results are in agreement with the findings of Bhatt et al. (2001) who also reported non-additive gene action for the trait. However, Pratta et al. (2003) reported prevalence of additive gene action for the genetic determination for number of flowers/cluster.

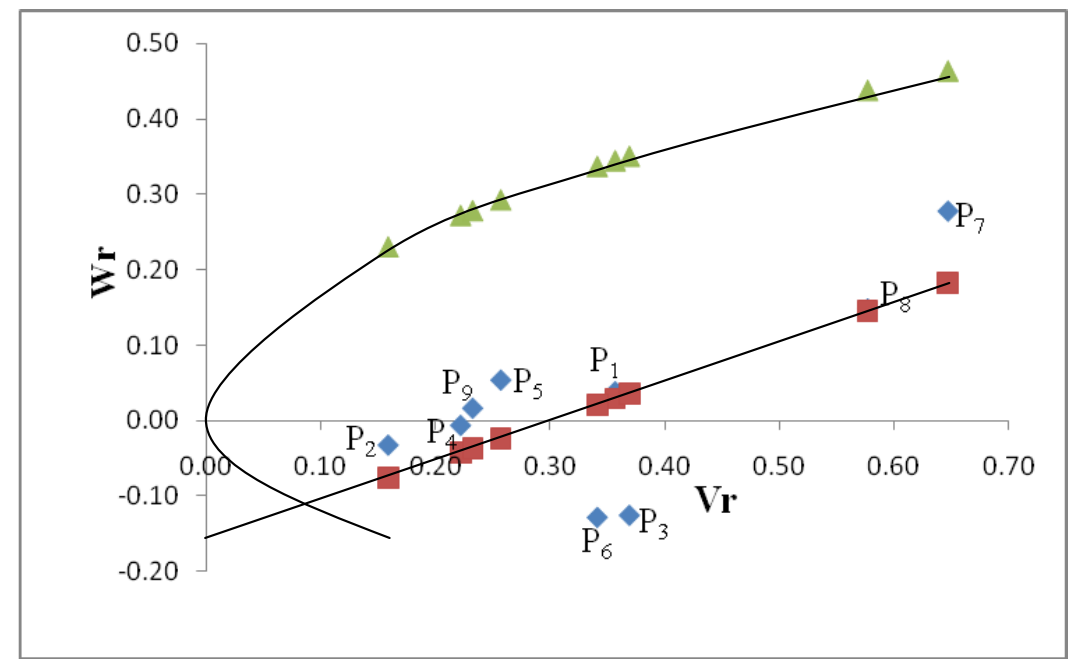

Fig. 1. Vr-Wr graph for number of flowers/cluster.

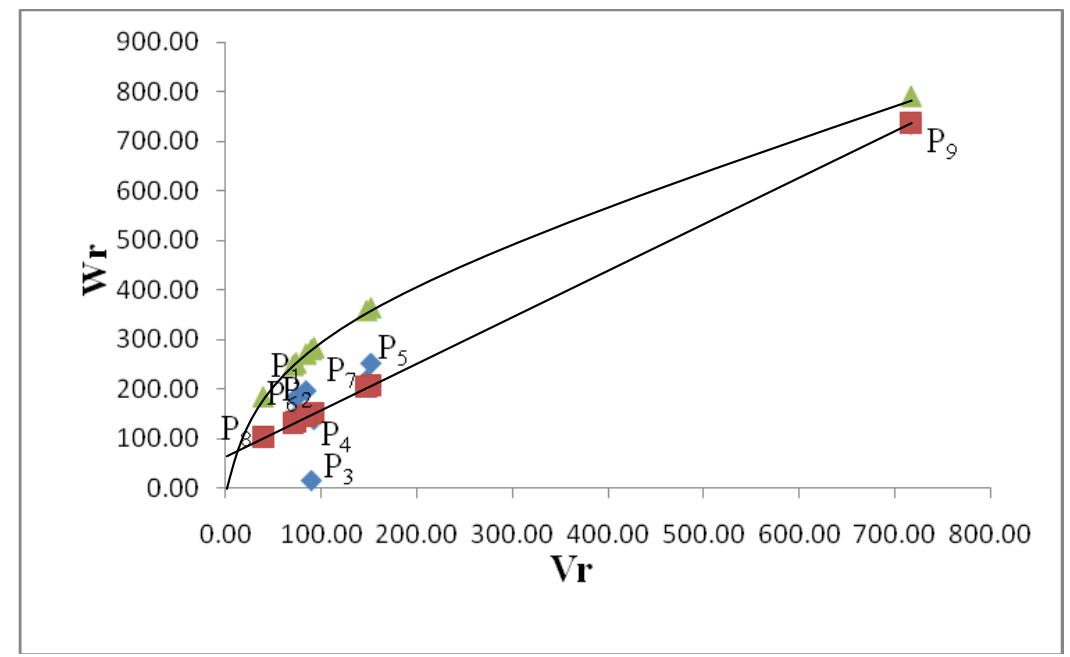

Fig. 2. Vr-Wr graph for individual fruit weight. 


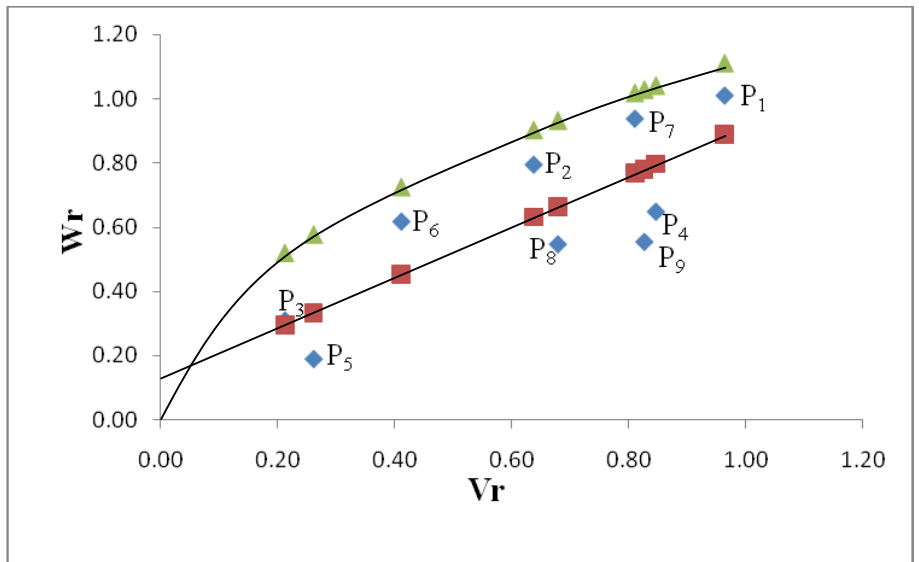

Fig. 3. Vr-Wr graph for fruit breath.

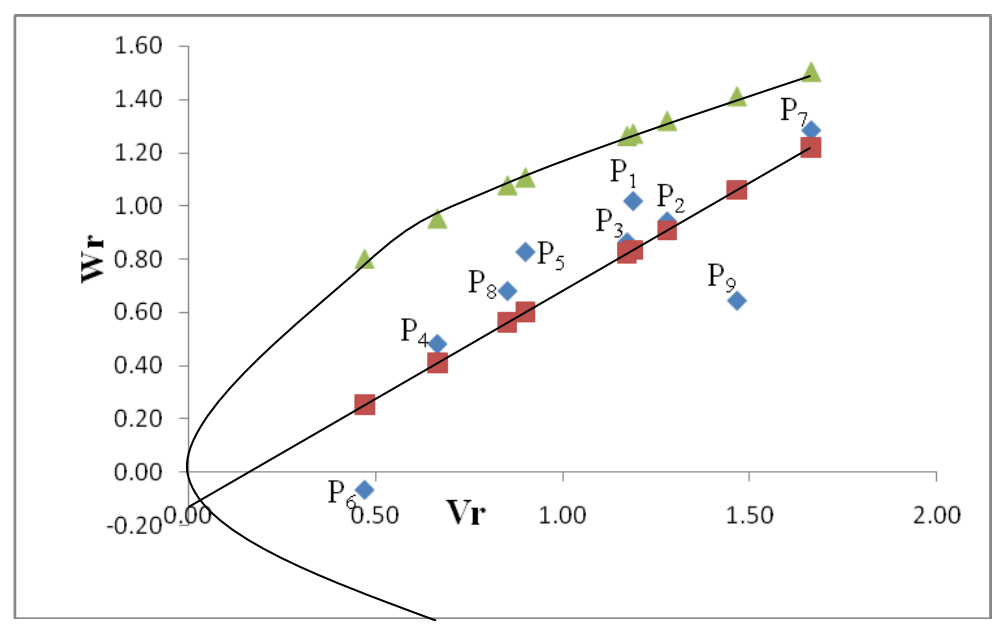

Fig. 4. Vr-Wr graph for number of locules.

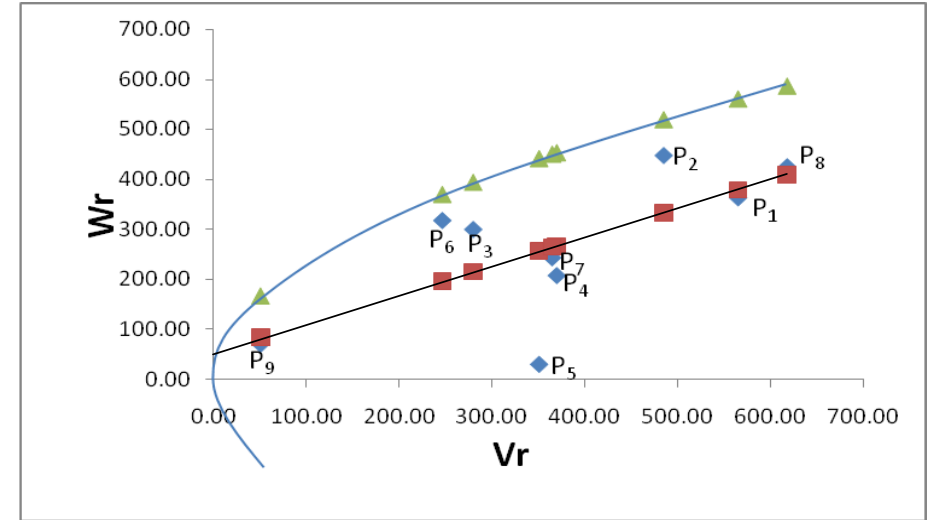

Fig. 5. Vr-Wr graph for number of seeds/fruit. 
Most of the recessive genes for both number of flowers/cluster (Fig.1) and number of locules (Fig.4) belonged to $\mathrm{P}_{7}$, while most dominant genes were possessed to $\mathrm{P}_{6}$. $\mathrm{P}_{5}$ contained most of the dominant genes and $\mathrm{P}_{1}$ had most of the recessive genes for fruit breath (Fig.3). $\mathrm{P}_{3}$ had most of the dominant genes for individual fruit weight (Fig.2), while $\mathrm{P}_{9}$ had most of the recessive genes. In case of number of seeds/fruit (Fig.5) most of the recessive genes were possessed by $\mathrm{P}_{2}$ and most of the dominant genes by $\mathrm{P}_{5}$.

Components of variance : From the table 4, it was observed that additive (D) and dominance variance $\left(\mathrm{H}_{1}\right.$ and $\left.\mathrm{H}_{2}\right)$ were highly significant for all the five characters - number of flowers/cluster, individual fruit weight, fruit breath, number of locules and number of seeds/fruit. The significant results instigated the importance of both additive and non-additive genetic variance in the inheritance of these five characters. Dominant component $\left(\mathrm{H}_{1}\right)$ was more predominant than additive component (D) except for individual fruit weight, where additive component was predominant.

Near equality of the two components $\mathrm{H}_{1}$ and $\mathrm{H}_{2}$ for fruit breadth indicated symmetry of dominant and recessive alleles distribution in parents, while the other four characters showed the unbalance distribution of dominant and recessive alleles. This finding was further strengthened by the value and sign of $F$. The significant positive value of $F$ for number of flowers/cluster, individual fruit weight and number of seeds/fruit suggested the more frequency of dominant alleles than recessive alleles, while negative value for number of locules indicated the prevalence of recessive alleles in parents. However, fruit breath had balance distribution of both the dominant and recessive alleles. Ameri et al. (2009) also found equal frequencies for positive and negative alleles in the parents for fruit breath, but unlikely they got balance distribution for fruit length too. The results were confirmed by the ratio $\left\{\left(4 \mathrm{DH}_{1}\right)^{1 / 2}+\mathrm{F}\right\} /\left\{\left(4 \mathrm{DH}_{1}\right)^{1 / 2}-\mathrm{F}\right\}$. The ratio with higher value than unity indicated the asymmetric distribution and equal or near equal value to unity indicated the symmetric distribution of dominant and recessive alleles in parents.

The proportion of dominant genes with positive and negative effects is determined by $\mathrm{H}_{2} / 4 \mathrm{H}_{1}$ ratio, from which it was observed that except fruit breadth all the characters had dominant genes with irregular distribution (as the ratio deviated from 0.25 ) of increasing and decreasing effects in parents. The mean degree of dominance can be detected by $\left\{\left(\mathrm{H}_{1} / \mathrm{D}\right)^{1 / 2}\right\}$. The unit value for fruit breadth indicated the equal proportion of dominance and recessive alleles in parents. Higher value than unity for number of flowers/cluster, number of locules and number of seeds/fruit indicating the abundance of dominant alleles and deficit of recessive alleles, while individual fruit weight had the reverse alleles distribution as its value was less than unity. 
Table 4. Components of variance and genetic parameters for some yield components in an 9-parent diallel cross of tomato

\begin{tabular}{|c|c|c|c|c|c|}
\hline Components & $\begin{array}{c}\text { No. of } \\
\text { flowers/cluster }\end{array}$ & $\begin{array}{l}\text { Individual } \\
\text { fruit wt. }\end{array}$ & Fruit breadth & $\begin{array}{l}\text { No. of } \\
\text { locules }\end{array}$ & $\begin{array}{c}\text { No. of } \\
\text { seeds/fruit }\end{array}$ \\
\hline $\mathrm{D}$ & $\begin{array}{c}0.33 * * \\
\pm 0.0004\end{array}$ & $\begin{array}{c}869.63 * * \\
\pm 0.178\end{array}$ & $\begin{array}{c}1.28 * * \\
\pm 0.0005\end{array}$ & $\begin{array}{c}1.35^{* * *} \\
\pm 0.0007\end{array}$ & $\begin{array}{c}553.85 * * \\
\pm 0.3972\end{array}$ \\
\hline $\mathrm{F}$ & $\begin{array}{c}0.56^{* *} \\
\pm 0.0009\end{array}$ & $\begin{array}{c}861.95 * * \\
\pm 0.415\end{array}$ & $\begin{array}{c}0.06 * * \\
\pm 0.0012\end{array}$ & $\begin{array}{l}-0.25 * * \\
\pm 0.0016\end{array}$ & $\begin{array}{l}38.75 * * \\
\pm 0.9267\end{array}$ \\
\hline $\mathrm{H}_{1}$ & $\begin{array}{c}1.63 * * \\
\pm 0.0008\end{array}$ & $\begin{array}{c}641.66^{* *} \\
\pm 0.393\end{array}$ & $\begin{array}{c}1.30 * * \\
\pm 0.0012\end{array}$ & $\begin{array}{c}2.68 * * \\
\pm 0.0016\end{array}$ & $\begin{array}{c}964.79 * * \\
\pm 0.8768\end{array}$ \\
\hline $\mathrm{H}_{2}$ & $\begin{array}{c}1.25 * * \\
\pm 0.0007\end{array}$ & $\begin{array}{c}382.52 * * \\
\pm 0.338\end{array}$ & $\begin{array}{l}1.21 * * \\
\pm 0.001\end{array}$ & $\begin{array}{c}2.09 * * \\
\pm 0.0013\end{array}$ & $\begin{array}{c}640.16^{* *} \\
\pm 0.7537\end{array}$ \\
\hline$h^{2}$ & $\begin{array}{c}1.01 * * \\
\pm 0.0005\end{array}$ & $\begin{array}{c}662.08 * * \\
\pm 0.226\end{array}$ & $\begin{array}{c}0.09 * * \\
\pm 0.0007\end{array}$ & $\begin{array}{c}0.003 * \\
\pm 0.0009\end{array}$ & $\begin{array}{c}177.92 * * \\
\pm 0.5049\end{array}$ \\
\hline $\mathrm{E}$ & $\begin{array}{l}0.002 * * \\
\pm 0.0001\end{array}$ & $0.15^{*} \pm 0.0563$ & $\begin{array}{l}0.00003 \\
\pm 0.0002\end{array}$ & $\begin{array}{l}0.003 * * \\
\pm 0.0002\end{array}$ & $\begin{array}{c}0.44 * * \\
\pm 0.1256\end{array}$ \\
\hline$\left(\mathrm{H}_{1} / \mathrm{D}\right)^{1 / 2}$ & 2.22 & 0.86 & 1.01 & 1.41 & 1.32 \\
\hline $\mathrm{H}_{2} / 4 \mathrm{H}_{1}$ & 0.19 & 0.15 & 0.23 & 0.19 & 0.17 \\
\hline $\begin{array}{l}\left\{\left(4 \mathrm{DH}_{1}\right)^{1 / 2}+\mathrm{F}\right\} \\
/\left\{\left(4 \mathrm{DH}_{1}\right)^{1 / 2}-\mathrm{F}\right\}\end{array}$ & 2.23 & 3.73 & 1.05 & 0.88 & 1.05 \\
\hline$r_{x y}$ & -0.52 & $0.91 * *$ & -0.30 & 0.17 & -0.32 \\
\hline$r^{2}$ & 0.27 & 0.83 & 0.09 & 0.03 & 0.10 \\
\hline $\mathrm{h}^{2} / \mathrm{H}_{2}$ & 0.81 & 1.73 & 0.08 & 0.001 & 0.28 \\
\hline
\end{tabular}

The significant $\mathrm{E}$ value for all the characters except fruit breadth instigated the drastic influence of environment on these traits. The correlation coefficient (r) between parental measurement (Yr) and parental order of dominance $(\mathrm{Wr}+\mathrm{Vr})$ was positive and significant for individual fruit weight indicating that the parents had dominant alleles with negative effects. Again, negative correlation coefficient for number of flowers per cluster, fruit breadth and number of seeds per fruit revealed recessive alleles to have positive effects. The completely dominant or recessive parents prediction were not possible as $r^{2}$ was not less than unity for all the five traits. Number of blocks of dominant genes was estimated from $\mathrm{h}^{2} / \mathrm{H}_{2}$ ratios, which was the highest for individual fruit weight (1.73) and lowest for number of locules.

Based on these information it may be concluded that the importance of both additive and non-additive genetic parameters suggests the use of integrated breeding strategies for tomato improvement. The use of hybrid breeding accompanied with recurrent selection may provide ample opportunities for novel recombination and accumulation of genes of interest. 


\section{Refernces}

Ahmed, S., M.M. Rahman, A.K.M. Quamruzzaman and M.N. Uddin. 2010. Genetic analysis of quantitative characters in heat tolerant tomato (Solanum lycopersicum L.). J. Innov. Dev. Strategy. 4(1):27-33

Amiri, O. H., M.H. Fotokian, F. Javidfar and B. Alizadeh. 2009. Genetic analysis of grain yield, days to flowering and maturity in oilseed rape (Brassica napus L.) using diallel crosses. Intl. J. Plant. Prod. 3(2): ISSN: 1735-8043.

Annonymous. 2014. Year Book of Agricultural Statistics of Bangladesh. Bangladesh Bureau of Statistics, Ministry of Planning, Government of Peoples' Republic of Bangladesh, Dhaka.

Balestrieri, M.L., R. De Prisco, B. Nicolaus, P. Pari, V.S. Moriello, G. Strazzullo, E.L. Iorio, L. Servillo and C. Balestrieri. 2004. Lycopene in association with Rtocopherol or tomato lipophilic extracts enhances acyl- platelet - activating factor biosynthesis in endothelial cells during oxidative stress. Free Radical Biology and Medicine. 36: 1058-1067.

Bhatt, R.P., V.R. Biswas and N. Kumar. 2001a. Heterosis, combining ability and genetics for vitamin $\mathrm{C}$, total soluble solids and yield in tomato (Lycopersicon esculentum Mill.) at 1700m altitude. J. Agric. Sci. 137: 71-75

Bhutani, R.D. and G. Kalloo. 1991. Inheritance studies of locule number in tomato Lycopersicon esculentum Mill.). Haryana J. Hort. Sci. 20: 1-2.

Erdman, J.W., N.A. Ford. and B.L. Lindshield. 2009. Are the health attributes of lycopene related to its antioxidant function. Arch. of Biochem. and Biophysics. 483: 229-235.

Gul, R. 2011. Characterization and inheritance studies of desirable attributes in tomato. PhD Thesis. Department of Plant Breeding and Genetics. University of Peshawar, Pakistan.

Hayman, B. J. 1954a. The analysis of variance of diallel table. Biometrics. 10: 235-244.

Hayman, B. J. 1954b. The theory and analysis of diallel crosses. Genetics. 39: 789-809.

Jinks, J. L. and B. I. Hayman. 1953. The analysis of diallel crosses. Maize Genet. Crop. News Letter. 27: 48-54.

Mather, K. and J. L. Jinks. 1982. Biometrical Genetics. Chapman and Hall, New York.

Paratta, G., R. Zorzoli and L.A. Picardi. 2003. Diallel analysis of production traits among domestic, exotic and mutant germplasms of Lycopersicon. Genet. And Mol. Res. 2(2): 206-213.

Prakash, A. and A. Kumar. 2014. Implicating the role of lycopene in restoration of mitochondrial enzymes and BDNF levels in $\beta$-amyloid induced Alzheimer's disease. European J. Pharmacology. 741: 104-111. 